\title{
HOTS QUESTION ON STUDENTS' WRITING ABILITY IN REPORT TEXT AT BUSINESS MURNI SADAR POLYTECNIC
}

\author{
Doris Yolanda Saragih ${ }^{1)}$, Poltak Pardamean Simarmata ${ }^{2)}$ \\ ${ }^{1}$ Teknik Komputer, Politeknik Bisnis Indonesia \\ email: dorisyolandasaragih@gmail.com \\ ${ }^{2}$ Manajemen, Sekolah Tinggi Akuntansi dan Manajemen Indonesia \\ email: poltak.pardamean@sbm-itb.ac.id
}

\begin{abstract}
This research was about applying HOTS question on students' writing ability in report text at Business Murni Sadar Polytechnic, which the problem of this research was "What extent to the students' writing ability in report text by applying HOTS question at Business Murni Sadar Polytechnic?" and the objective of this research was to find out the extent of students' writing ability in report text by applying high order thinking skill (HOTS) question at Business Murni Sadar Polytechnic. The method that used in this research was quantitative research design. The population of this research was students of Business Murni Sadar Polytechnic Population of this research were 100 students. The sample of this research were 60 students with divided into 30 students as experimental class and 30 students of as control class. The analysis of this research showed that the mean score of pre- test of the experimental group was 53, 566 and control group was 54, 1. The mean of post-test of the experimental group was 82, 066 and control group was 67, 033. Testing hypothesis showed that t-test (4,0003) was higher than t-table $(1,671)$ at level of significant 5\% for two tailed test. It meant that applying HOTS Question on students' writing ability in report text gave a good contribution. Based on the result, it can be seen that the students' writing ability in report text increased. It meant that there was an extent (improvement) of students' writing ability in report text by applying HOTS Question at Business Murni Sadar Polytechnic.
\end{abstract}

Keywords : Host Question, Report Text, High Order Thinking Skill.

\section{BACKGROUND OF RESEARCH}

Writing is one of skills in teaching and learning English. By writing, students can explore their ideas, give many arguments and communicate many information in written form. Kirby and Crovitz [1] state that writing is an act of creation, which makes writing instruction uniquely different from many other kinds of teaching. This is also close to state that writing is the ability to construct the ideas in written from such as text, memos, etc. Writing has always occupied a place in most English language course.

Having good writing skill can help every students to be more active in combining words and completing every words into sentence even though according to Nik, Hamzah \& Rafidee, writing is reported as the most difficult skill to be acquired as it involves a number of skills and conventions. Some of the reason why writing is difficult because the students don't have a good grammar, spelling and vocabulary. Stated that writing is difficult for the students because they lack vocabulary, spelling, and grammar. Furthermore state that the most problem of students in writing is in generating ideas.

When the students can make a good writing, they also can express whatever they are thinking. It can be like their information, opinion, comment, or even what they feelings are. It will be easy for them to inform many important ideas and 
knowledge that they have gotten in written form. Basic competencies that must be realized in writing English subject is that at least students have the ability to develop and produce simple functional texts written in descriptive texts, recount texts, narrative texts and especially report text. One of the way to solve those problems to build ideas and develop students' imagination in writing report text is applying high order thinking skill (HOTS) question. According to Ganapathy \& Kaur [2], HOTS is considered as the important skills to make innovative and creative individuals. In the learning process, students not only focus on remembering, understanding and applying but they have to have the abilities like analyzing, evaluating and creating ideas. It can help them to think creatively and critically like when they're answering the question. Basically, Teachers use various question types as a means of measuring students' understanding as well as to ensure that the learning process of a particular subject has taken place [3]. Making some questions as form of assessment is one of the things that teacher should prepare first. A good question is question that has a relevant relationship with what will be answered according to the different level of easy or hard the question is[4].

Questioning that combined by high order thinking skill (HOTS) can help the development of student critical thinking levels. The level, type and structure of questions are important to the discussion in classroom teaching learning process. HOTS provides students with a new shared vocabulary for their critical contributions to be discussed. Higher order level questions are those that ask how and why something happens or how one event, object or idea might be related to other events, objects or ideas [5][6].

Therefore, by applying this HOTS questions, hopefully this stimulation as strategy or method can solve students' difficulties in writing report text. It is good influence to help students construct their ideas to be completed information with good vocabulary and grammar actually. Based on the statement above, researchers are interested in conducting research with the title is "Applying HOTS Question on Students' Writing Ability in Report Text at Bussiness Murni Sadar Polytechnic"

Problem of Research

The researcher states that the problem of this research is 'what extent to the students' writing ability in report text by applying high order thinking skill (HOTS) question at Bussiness Murni Sadar Polytechnic?'

Objective of Research

The objective of this research is to find out the extent of the students' writing ability in report text by applying high order thinking skill (HOTS) question at Bussiness Murni Sadar Polytechnic.

Scope of Research

In conducting this research, the researcher makes the scope. The researcher only focuses on students' writing ability at Bussiness Murni Sadar Polytechnic who are still low in writing, especially in generic structure and they need an improvement for it. Significances of The Research

The Hypothesis of Research

The research hypothesis is proposed in terms of alternative hypotheses (Ha) and the null hypothesis (Ho). They are as follows:

$\mathrm{Ha}$ : There is an extent of the students' writing ability in report text by applying high order thinking skill (HOTS) question at Murni Sadar Business Polytechnic

Ho : There is no extent of the students' writing ability in report text by applying high order thinking skill (HOTS) question at Murni Sadar Business Polytechnic

\section{Review of related literature}

A. Writing

1. The Definition of Writing

Writing is a productive skill. Writing is the mental work of inventing ideas, thinking how about to express them, and organizing them into statements and paragraphs that will be clear to a reader.

2. Writing Skill

Writing skill is very useful to communicate our ideas into a written text so the readers will understand and know the aim 
of our written. Writing skill is complex and difficult to teach since in this case writing does not only mean putting down graphic form on a piece of paper. Williams [7] states that in some situation, a writer may not be responsible for editing.

The researcher state that writing skill is the ability to write information and ideas which has some ways to make it successful. Those ways are pre-writing as the moment to generate the idea, planning as the moment to prepare the information, drafting as the moment to produce words, pausing as the moment of writer to take a little of break, reading as the moment during pausing of writer to read his/her written and to compare it to writer's plan, revising as the moment to make a chance, editing as the moment to focus on sentence level concern, and publishing as the moment to share the written that has finished.

\section{The Important of Writing}

Byrne stated that there are many reasons why writing is important, some of them are: (1) Writing generates new ideas by helping us to make connection and see relationship. (2) Writing helps to organize the ideas; arranging them in coherent form. (3) Writing down ideas allows writer distance theirselves from them and evaluate them. (4) Writing helps us to absorb and process information, when we write about topic, we learn it better.

Writing is very important in teaching and learning process. It can helps student in many aspect especially in their future because by writing they can produce, explore and generate a new information creatively so in the future they can share a good knowledge in written form.

\section{The Components of Writing}

Carroline [8] mentioned that writing is not only drawing some words on a piece of paper and formulating letter together. Writing is about meaning. If you just write letter and it does not have meaning it is not classified as writing. Writing needs some components to make it as a good writing and has meaning.

Based on the explanation above the researcher state that writing has five components. Those components are organization as the ability to understand the meaning, content as the ability to produce an idea, grammar as the ability to construct every words into a good sentence, punctuation the ability to spell, and style as the ability to use vocabulary.

B. Report Text

Hampton et al. states that a report text classifies and describes the fact of things in the social and natural world. It gives details, often physical, about such things as animals, plants, weather, medicine, machines, and countries

\section{High Order Thinking Skill (HOTS)}

According to Heong, et al higher order thinking is using the thinking widely to find new challenge. Higher order thinking demands someone to apply new information or knowledge that he has got and manipulates the information to reach possibility of answer in new situation. Brookhart [7] states that higher- order thinking conceived of as the top end of the Bloom's cognitive taxonomy. Krathwohl [9] state that the categories which considered as HOTS are analyze, evaluate, and create.

Effective questions enable learner's to focus their attention to make sense on the content of the lesson, increase their curiosity, activate their imagination, and motivate them to acquire new knowledg. Thus, the teacher needs to be aware on the difficulty level of the question and the students' cognitive growth.[8] labelled that teachers are very good at thinking spontaneously, however without well preparation and objective in mind, they will likely asking questions that are not stimulate students' higher order thinking. A good proportion of questions is ideal, where not every questions and discussion has to be pitched at higher order thinking. Collins [8] added, the questions should be built to encourage students to reflect on their learning, which will allow them to acknowledge their thinking strength and weakness.

\section{The Benefits of HOTS}

Some research that have been done by experts showed the application of higher order thinking skills have a very positive impact on 
the learning process. The benefits of higher order thinking skills [7] are given as follow.

- Increase student achievement

The use of tasks and judgments that require intellectual and critical thinking skills are associated with student's achievement progress. The progress are shown in various learning outcomes, such as standard test scores. Wenglinsky [7] describes his research on students' ability relationships in large-scale measurements and teaching that emphasize higher order thinking skills, projects, and problem solving.

Wenglinsky reports that teaching that emphasizes reasoning is associated with increasing values in all tests at various grade levels. Newmann, Bryk, and Nagaoka [7] explained that students who receive teaching through higher order thinking skills can solve problems by organizing their knowledge and experience, able to elaborate their statements or opinions, and to complete non-familiar tasks.

- Increase student motivation

Several studies have shown that teachers are responsible for higher order thinking skills using tasks and judgments. These things need understanding and critical thinking to improve student motivation as well as student achievement. Students will not be interested or motivated by abstractmaterial and abstract teaching. Students will be interested in thinking about particular or detail things which make them motivate to learn. Higher order thinking skills increases their interest in mastering their ideas. Students will think more fun than just remembering [7].

\section{RESEARCH METHODOLOGY}

A. Research Design

This research was design quantitative research. This research conducted to see the extent of the students' writing ability in report text based on high order thinking skill (HOTS) question at Bussiness Murni Sadar Polytechnic . According to Ary, Jacobs, and Sorensen[10], an experiment is a scientific investigation in which the researcher manipulates one or more independent variables, control any other relevant variables, and observe the effect of manipulation on the dependent variables.

Table 2: Research Design

Group Pre-test Treatment

Experimental E1 $\mathrm{X}$

Control C1 - $\quad \mathrm{C} 2$

Notes:

$\mathrm{X}$ : teaching by using scientific approach $\mathrm{Y} 1$

: Pre-test

Y2 : Post test

B. Location of Research

This research conducted in Bussiness Murni Sadar Polytechnic. The researcher wanted to know the extent of the students' ability at Bussiness Murni Sadar Polytechnic . Therefore, the researcher conducted a research to solve the problem by applying HOTS question that was expected to be useful for the teacher, students, and the next researchers.

C. Population and Sample

1. Population

A population was defined as all members of any well-defined class of people, events, or objects. (Ary, Jacobs, and Sorensen, 2010: 148). The target population of this study were the students of Bussiness Murni Sadar Polytechnic.

2. Sample

According to Ary, Jacobs, and Sorensen [10] state that Sample is a portion of a population. It was impossible to use all the population as the sample due to some considerations. The researcher was taken two class as the sample of the research. The two class are experimental group and the control group. The experimental group was given HOTS question and material about report text while the control group was given the same materials but without using HOTS question

Table 2.1: The sample of research

No Class Total Group

1 A $30 \quad$ Experiment

2 B $30 \quad$ Control

D. Instrument of The Research

The researcher used essay test as the instrument of this research to know the ability of students in writing report text. The topic that the researcher gave was about Indonesian Economy . The researcher gave the pre-test, treatment and post-test as the type of the test 
E. Validity and Reliability

1. Validity

According to Ary, Jacobs, and Sorensen [10] state that content validity refers to the extent to which instrument represent to the content of interest. It could be taken from textbooks, states' curriculum guides or even syllabus.

In this study, content validity was using because the result of test can be representative of the student for entire course material that had been taught

Table 2.2: validity of test

\begin{tabular}{|c|c|c|c|c|}
\hline \multirow{2}{*}{ Content } & \multirow[b]{2}{*}{ cators } & $\mathrm{t}^{\mathrm{Tes}}$ & $\begin{array}{c}\text { Kind } \\
\text { of }\end{array}$ & \multirow{2}{*}{ Score } \\
\hline & & $\begin{array}{l}\text { Ite } \\
\mathrm{ms}\end{array}$ & test & \\
\hline Title & Word or Phrase & 1 & essay & 5 \\
\hline $\begin{array}{l}\text { General } \\
\text { Identification }\end{array}$ & Identify place & 1 & essay & 10 \\
\hline \multirow[t]{6}{*}{ Description } & Parts & 2 & essay & 15 \\
\hline & Qualities & 2 & essay & 15 \\
\hline & Characteristic & 2 & essay & 15 \\
\hline & Problem & 1 & essay & 25 \\
\hline & Solution & 1 & essay & 15 \\
\hline & Total & 10 & & 100 \\
\hline
\end{tabular}

\section{Reliability}

According to Ary, Jacobs, and Sorensen [10], Reliability is the extent to which the test measures accurately and consistently. Defined reliability as necessary characteristic of any good test: to be valid at all, a test should first reliable as a measuring instrument. Reliability refers to the consistency of the scores obtained and how consistent was.

F. Technique of Data Collection

There were some step that applied, they were: Pre-test, Treatment, and Post-test.

1. Pre-test

Before the researcher taught a material, the researcher gave a test to the students. The researcher asked all of students to answer the essay test. Same test was given to both experimental and control class to get the preliminary data to be compared with the post test.

2. Treatment
After conducting the pretest, the researcher conducted a treatment. Experimental class was taught by question based on high order thinking skill while in control class, there was no treatment.

\section{Post test}

Same test was given to both experimental and control class as post-test. The researcher asked the students to complete an essay test. Then, the researcher compared their score before and after giving treatment.

G. Technique of Analyzing Data

After the researcher collected the data and then the researcher analyzed the data by following the steps:

\section{- $\quad$ Scoring Test}

The researcher analyzed and gave the score to students' writing report text. Scoring the students' work was a step to obtain quantitative information from each student. One of the way to score or to evaluate the students' achievement was rating scale. The following scheme of rating scale was used to measure the students' achievement in students' written product.

To score students' writing test, the researcher used scoring rubric that adapted from Brown [11].

Table 2.3: The Written Assessment Rubric

\begin{tabular}{|c|c|c|c|}
\hline Aspect & Score & $\begin{array}{l}\text { Performance } \\
\text { Description }\end{array}$ & $\begin{array}{c}\text { Weigh } \\
\text { ting }\end{array}$ \\
\hline $\begin{array}{l}\text { Content (C) } \\
30 \% \\
\text {-topic }\end{array}$ & 4 & $\begin{array}{l}\text { The topic is } \\
\text { complete and } \\
\text { clear and the data } \\
\text { details are relating to } \\
\text { the topic }\end{array}$ & \multirow{4}{*}{$3 x$} \\
\hline \multirow[t]{3}{*}{-details } & 3 & $\begin{array}{l}\text { The topic is } \\
\text { complete and clear } \\
\text { but the details are } \\
\text { almost relating to the } \\
\text { topic }\end{array}$ & \\
\hline & 2 & $\begin{array}{c}\text { The topic is } \\
\text { complete and } \\
\text { clear but the details } \\
\text { are not relating to the } \\
\text { topic }\end{array}$ & \\
\hline & 1 & $\begin{array}{l}\text { The topic is not clear } \\
\text { and } \\
\text { the details are not } \\
\text { telating to the topic }\end{array}$ & \\
\hline
\end{tabular}




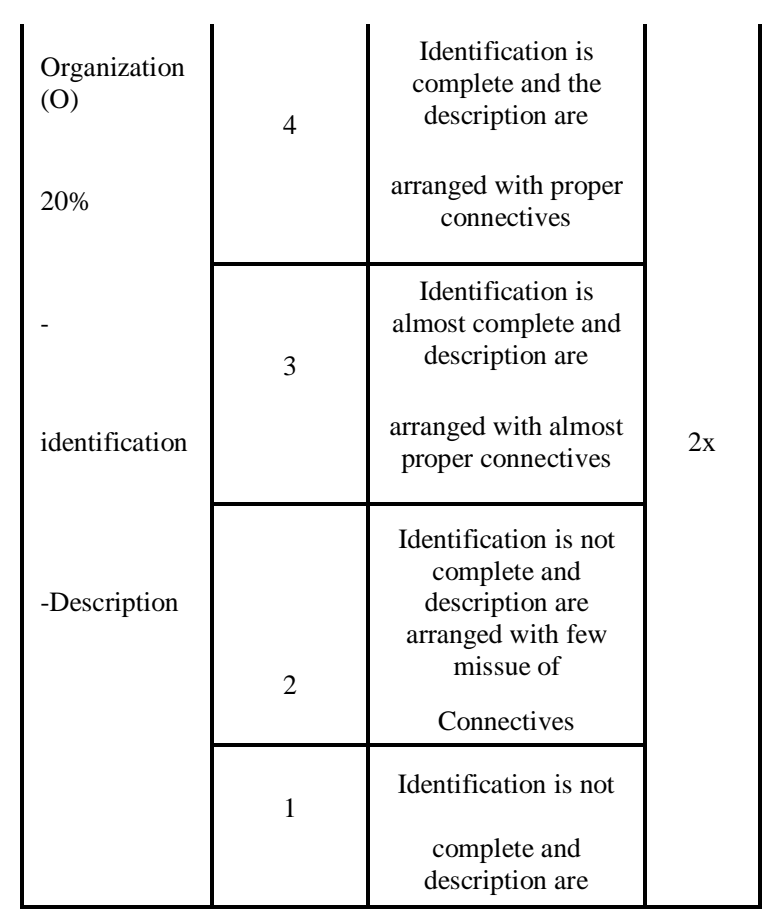

Score $=\frac{3 \mathrm{C}+2 \mathrm{O}+2 \mathrm{G}+1,5 \mathrm{~V}+1,5 \mathrm{M}}{40}$

- $\quad$ Testing Hypothesis

$$
t_{\text {test }}=\frac{\overline{\not e}-\bar{X}}{S E \overline{(\chi e-\chi c)}}
$$

Notes:

$t_{\text {test }}=$ Testing Hypothesis

$\bar{X}=$ Mean of Post Test in Experimental

$\bar{X}=$ Mean of Post Test in Control

$S E(\chi e-\chi c)=$ standard error

\section{DATA ANALYSIS, RESEARCH FINDING}

This chapter discussed about the analysis of the data. The concept of this chapter was based on the theories that previously were mentioned in chapter II and III. Data analysis classified the writing scores of experimental group and control group, the students' development of experimental group and control group, standard deviation of experimental class and control class, t-test, testing hypothesis, research findings and discussion.

\section{A. Data Analysis}

The data were taken from the test which are pre- test and post- test. There were 60 students as the sample of the research. It was 30 students as the experimental group and 30 students as the control group. The data used essay test. It was taken after the researcher taught report text by applying HOTS questions to the experimental group and conventional teaching technique to the control group. The researcher arranged the data based on five elements of writing skills. Those are content, organization, grammar, vocabulary, and mechanics.

1. Analyzing Data in Experimental Class

The data were taken by the test which are pre- test and post- test of students. It was taken by applying HOTS questions. Here the data of the students' writing ability in report text on experimental class.

The test was tested in order to know the students' wrijong ability in report text. In pretest, the test was done before applying HOTS question while in post- test was done after applying HOTS question. Based on those total score, the researcher found the mean (the average score) of pre- test in experimental class was 53, 5667the mean score of post- test in experimental class was 82, 066.

2. Analyzing Data in Control Class

The test was tested in order to know the students' writing ability in report text. Pretest and post- test were done by conventional teaching technique. Based on the total score, the researcher found the mean (the average score) of pre- test in control class was 54, 1 while the mean score of post- test in experimental class was 67, 033 .

3. The Students' Development of Experimental Group and Control Group

The students' development was doing to find out an improvement on students' writing ability in report text. The data were taken by making comparison between students' score of the pre- test and post- test in experimental class and students' score of pre- test and posttest in control class. Here the students' development of experimental group and control group can be seen 
The Students' Development of Experimental Group and Control Group

\begin{tabular}{|c|c|c|c|}
\hline Group & $\begin{array}{l}\text { Pre- } \\
\text { Test }\end{array}$ & $\begin{array}{l}\text { Post- } \\
\text { Test }\end{array}$ & Improvement \\
\hline Control & 54.1 & 67.033 & 12.933 \\
\hline
\end{tabular}

Ttest $=4,0003$

5. Finding out the degree of freedom (df): 58

T-table at $5 \%$ of level of significance is $\mathbf{1 , 6 7 1}$

Based on the formula of hypothesis which was designed before, Null Hypothesis is rejected if the t-test is higher than t-table. Referring to this, the hypothesis could be constructed as follow:

$\mathrm{t}$-test $>\mathrm{t}$-table of $5 \%$

$4,0003>1,671$

As the score of t-test $(4,0003)$ was higher than t-table $(1,671)$ at the level of significance $5 \%$ for two tailed test, so Null Hypothesis is rejected and Alternative Hypothesis is accepted. It can be concluded that there was an improvement of the students' writing ability in report text by applying HOTS (high order thinking skill) question than without applying HOTS question at Murni Sadar Business Polytechnic B. Research Findings

Based on the work of the data analysis, some findings can be formulated as follow: There is a significant extent of applying HOTS question to the students' writing ability in report text at Murni Sadar Business Polytechnic. From the data analysis, testing hypothesis showed that $\mathrm{t}$-test $(4,0003)$ was higher than t-table $(1,671)$ at level of significant $5 \%$ for two tailed test.

\section{Discussion}

High Order Thinking Skill (HOTS) question is a suitable way that applied in the classroom in teaching writing ability in report text at Murni Sadar Business Polytechnic . The result of this research showed that score of post- test in the class that taught by applying HOTS question (Experimental class) was higher than post- test in the class without applying HOTS question (Control class). It meant that HOTS question had influenced on students' achievement ability in writing report text. HOTS Question is a way that designed for giving students skills to overcome the problems. So that they become addicted to learn more and increased students' writing. According to Moss \& Lapp [12] Report text requires students to explore factual information and create a format for sharing information. The purpose of report text is to inform the audiences what a topic is. It was explained that report text must include important information that considered to write as a report form.

From analysis of the data, the researcher found that the mean scores in control group of Pre-test was 54, 1 and Posttest was 67,033 . In other side, the mean score in experimental group of pre-test was 53, 566 and post-test was 82, 066 in experimental group. The researcher also found that the score of t-test $(4,0003)$ was higher than t-table $(1,671)$ at the level of significance $5 \%$ for two tailed test.

The researcher used two classes from the ten class as the sample that consist of 30 students of each class. One class was chosen to be experimental class that was received treatment by using HOTS questions technique. Based on the explanation above, the researcher's experience showed that applying HOTS questions could developed the students' writing ability in report text at grade ten of Poyitecnick Bisnis Indonesia.

\section{CONCLUSION AND SUGGESTION}

\section{A. Conclusion}

Based on the research finding, the researcher found that there was an extent (improvement) of students' writing ability in report text by applying HOTS Question at Business Murni Sadar Polytecnic . Based on the data analysis of the research, the result indicates that the alternative hypothesis (Ha) was accepted. It meant that applying HOTS Question very recommended for students to help them to create and arrange information or idea on written form especially at writing report text.

\section{B. Suggestion}

It is important for English teacher and students to be creative in the classroom by 
applying HOTS Question in order to have a successful teaching and learning process.

\section{REFERENCE}

[1] D. L. Kirby and D. Crovitz, Inside out Stategy for Teaching Writing, Fourth Edi. Portsmouth: Heinemann, 2013.

[2] M. Ganapathy and S. Kaur, "ESL Students' Perceptions of the use of Higher Order Thinking Skills in English Language Writing," Adv. Lang. Lit. Stud., vol. 5, no. 5, 2014, doi: 10.7575/aiac.alls.v.5n.5p.80.

[3] T. Kerry, Explaining and Questioning. UK: Cheltenham, 2002.

[4] H. Husin, "Dimensions of Questioning: A Qualitative study of Current Classroom Practice in Malaysia," Univ. Malaysia Sabah, Malaysia, vol. 10, no. 2, 2006.

[5] N. Athanassiou, J. M. McNett, and C. Harvey, "Critical Thinking in The Management Classroom," J. Manag. Educ., vol. 27, no. 1, p. 543, 2003.

[6] K. Hyland, Genre and Second Langage Writing. Michigan: The University of Michigan Press, 2004.

[7] S. M. Brookhart, How to Assess Higher Order Thinking Skills in Your Class- room. Alexandria: ascd, 2010.

[8] R. Collins, "Skills for the 21st century: Teaching higher-order thinking," Curric. Leadersh. J., vol. 12, no. 14, 2014.

[9] L. W. Anderson and D. R. Krathwohl, A taxonomy for learning, teaching and assessing: A revision of Bloom's taxonomy of educational objectives. New York: Longman, 2001.

[10] J. Ary and Sorensen, Introduction to Research in Education, 8th ed. USA: Wadsworth, 2010.

[11] H. D. Brown, Teaching by Principles: An Interactive Approach to Language Pedagogy, 2nd ed. New York: Longman, 2007.

[12] T. Kerry, Explaining and Questioning. UK: Nelson Thornes., 2002. 